\title{
147. Osteosarcoma Induced in Rats by Murine Sarcoma Virus (Moloney)*
}

\author{
By Kyoko Kano-TANAKA,**) Tatsuya TANAKA,**) \\ and Kazuto IKEMOTO***)
}

(Comm. by Sajiro MaKino, M. J. A., Oct. 12, 1974)

Tanaka et $a l_{0}{ }^{1)}$ reported the predominant induction of osteosarcomas in rats of Wistar-King-Aptekman (WKA/Mk) and some other strains by Moloney-isolated murine sarcoma virus (MSV-M). A consecutive cell-free passage initiated from this MSV-induced osteosarcoma was established in newborn rats as MSV-rat line (RPpassage), though tumor incidence by the RP-passage decreased during 8 passages. Repeated experiments have been carried out by us to isolate a rat-adapted MSV having a high osteosarcoma-inducing ability. Dmochowski et al. ${ }^{2}$ reported bone tumor virus (SD-MSV$\mathrm{M})$, highly tumorigenic for rats, mice and hamsters. This paper describes a new line of rat-osteosarcoma (RP2-passage) capable of cell-free passages through newborn WKA rats.

Materials and methods. Cell-free materials from C57BL/10J embryonic culture cells transformed by the MSV-M stock line, MP$7,{ }^{1)}$ were found to induce an osteosarcoma in one animal from a litter of WKA rats. Cell-free extract of this tumor served to initiate subsequent virus-passages in syngeneic rats. Only a single tumorous bone from the host bearing minimal lesions was selected as the source of inoculum. The tumor production occurred by either subcutaneous or intraperitoneal inoculations of virus suspension by the procedures described previously. ${ }^{1)}$ Some tumor-animals were X-rayed with Softex, type EMB ( $30 \mathrm{kV}, 8 \mathrm{~mA}, 20-25 \mathrm{sec}$. exposure), after fixing in $10 \%$ buffered formaldehyde solution.

Results. Tumor incidence by murine sarcoma virus (MSV-M) in WKA/Mk rats was summarized in Table I. From bone-tumor incidence and survival time, the virus activity was shown to increase particularly after the 5th passage. The virus-inocula more diluted than that of the 5th passage induced no tumors during 3-month-

*) This work was supported in part by a Grant-in-Aid for Fundamental Scientific Research from the Ministry of Education.

**) Laboratory of Cell Biology, Aichi Cancer Center Research Institute, Nagoya, 464.

***) Department of Orthopedic Surgery, Tottori University School of Medicine, Yonago, 683. 
Table I. Tumor induction in newborn $\mathrm{WKA} / \mathrm{Mk}$ rats by rat-adapted MSV-M (RP2-passage)

\begin{tabular}{|c|c|c|c|c|c|c|c|c|c|c|}
\hline \multirow{2}{*}{$\begin{array}{l}\text { Serial } \\
\text { pas- } \\
\text { sage }\end{array}$} & \multicolumn{3}{|c|}{ MSV inoculum } & \multirow{2}{*}{$\begin{array}{l}\text { No. of in- } \\
\text { duction/ } \\
\text { No. of } \\
\text { infected }\end{array}$} & \multirow{2}{*}{$\begin{array}{l}\text { Latent } \\
\text { period } \\
\text { (days) }\end{array}$} & \multirow{2}{*}{$\begin{array}{l}\text { Aver- } \\
\text { age } \\
\text { (days) }\end{array}$} & \multicolumn{4}{|c|}{ Incidence of tumors (\%) } \\
\hline & Route & $\begin{array}{l}\text { Dilu- } \\
\text { tion }\end{array}$ & $\underset{(\mathrm{ml})}{\operatorname{Amount}}$ & & & & Bone & $\begin{array}{l}\text { Bone } \\
\& \\
\text { spleen* }\end{array}$ & $\begin{array}{l}\text { Bone } \\
\& \text { soft } \\
\text { tissue }\end{array}$ & $\begin{array}{l}\text { Soft } \\
\text { tissue }\end{array}$ \\
\hline 2 & $i_{\text {ip }}$ & $\begin{array}{l}10^{0} \\
10^{0}\end{array}$ & $\begin{array}{l}0.1 \\
0.1,0.15\end{array}$ & $\begin{array}{c}2 / 2 \\
12 / 15\end{array}$ & & $\begin{array}{r}125 \\
71\end{array}$ & $\begin{array}{l}50 \\
33.3\end{array}$ & $\overline{33.3}$ & $3 \overline{3.3}$ & 50 \\
\hline 5 & $i_{\text {ip }}$ & $\begin{array}{l}10^{\circ} \\
10^{0}\end{array}$ & $\begin{array}{ll}0.1, & 0.15 \\
0.1, & 0.15\end{array}$ & $\begin{array}{r}3 / 10 \\
11 / 13\end{array}$ & & 33 & $\begin{array}{l}100 \\
9.7\end{array}$ & - & $\overline{80.6}$ & $\overline{9} .7$ \\
\hline 9 & $i_{i p}$ & $\begin{array}{c}10^{0} \\
10^{0} \\
5 \times 10^{-1} \\
2 \times 10^{-1}\end{array}$ & $\begin{array}{c}0.2 \\
0.1,0.15 \\
0.1 \\
0.1\end{array}$ & $\begin{array}{c}2 / 2 \\
17 / 17 \\
5 / 5 \\
5 / 5\end{array}$ & & $\begin{array}{l}35 \\
31 \\
27 \\
40\end{array}$ & $\begin{array}{r}100 \\
100 \\
100 \\
80\end{array}$ & $\begin{array}{l}\overline{-} \\
20\end{array}$ & $\begin{array}{l}\overline{-} \\
\bar{z}\end{array}$ & $\begin{array}{l}- \\
= \\
=\end{array}$ \\
\hline 12 & ip & $\begin{array}{l}1 \times 10^{-1} \\
1 \times 10^{-2}\end{array}$ & $\begin{array}{l}0.1 \\
0.1\end{array}$ & $\begin{array}{l}6 / 6 \\
1 / 2\end{array}$ & $\begin{array}{l}33-60 \\
97\end{array}$ & $\begin{array}{l}43 \\
97\end{array}$ & 100 & - & $\overline{100}$ & - \\
\hline
\end{tabular}

* Splenomegaly without involvement of leukemia.

** Sacrificed.

observations. The oncogenic activity at the 12th passage was shown to be over 10 times that of the earlier passages. The site and incidence of bone tumors corresponded to those previously described. ${ }^{1)}$ The RP2-passage induced a $100 \%$ incidence of bone tumors in rats. Virus inoculation by the intraperitoneal route (ip) produced more frequently multiple bone tumors than that by the subcutaneous route $(\mathrm{sc})$. The ip inocula also produced soft tissue tumors mainly in peritoneum, pancreas and diaphragm. They were of histologically mixed nature of rhabdomyosarcoma and angiosarcoma. Their incidence, however, decreased markedly in subsequent passages at the original virus concentration $\left(10^{\circ}\right) .{ }^{3)}$ The tumors were produced also with the virus dilutely concentrated at the 9th and 10th passage. Lesions noted as splenomegaly, cystic changes in lymph nodes and anemia induced were infrequent in the RP2-rats. Such soft tissue tumors developed late in host animals: This seems to indicate a prolonged survival time of the hosts permitting their growth to a considerable degree. However, pathological features provided no conclusive evidence for the above view. Further studies with purified virus clones are now in progress for analysis of multipotential oncogenicity of the RP2-virus.

Newborn BD IX rats appeared to be equally susceptible to the WKA-adapted virus: Of 18 newborn rats inoculated with $0.1 \mathrm{ml}$ of $10^{0}$ concentrate at the 9 th passage, 16 rats developed the tumor at the latent period ranging from 26 to 52 days, 36 days in an average. Although peritoneal or pleural effusions were produced in 8 of 18 rats $(44 \%)$, they were seldom found in WKA rats. A similar feature was shown by Dmochowski et al.2) 
The RP2-virus was known to produce in mice soft tissue tumors but not bone tumors. Such a species-specific tissue affinity to this virus persisted unaltered from our MSV-M stock. Although BALB/c mice were about $10^{3}$ times less sensitive to the RP2-virus at the 9 th and 12th passage than the original MSV-M stock, the susceptibility of rats to this virus increased about 10 times by repeated transmissions from rat to rat. Such a change of virus activity would be explicable
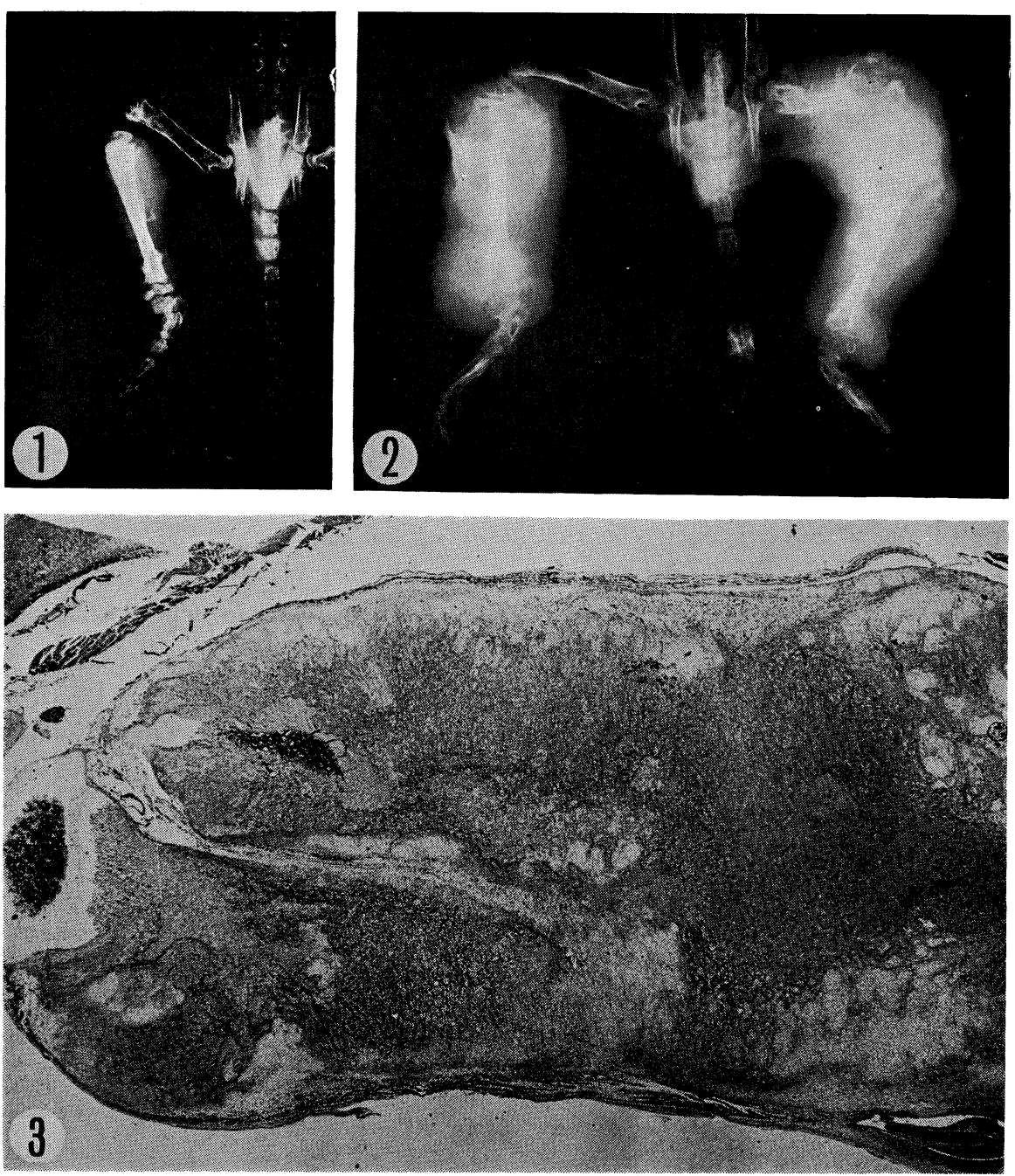

Fig. 1. Radiograph of early osteosarcoma of tibia and fibula of a 25-day-old WKA/Mk rat after MSV-M (RP2-passage 8 ) inoculation. $\times 1.4$

Fig. 2. Radiograph of advanced osteosarcoma of the hind legs of a rat in the same litter as in Fig. 1, 39 days after MSV inoculation. $\times 1.4$

Fig. 3. Photomicrograph of osteosarcoma of tibia and fibula from a 25-dayold rat in the same litter as above. H-E. $\times 9$ 
as a change in property of rat-adapted MSV. Further details will appear in another paper.

Some radiologic examinations of the tumors induced here revealed a new bone formation at the periosteum of the metaphyseal region of the long bone in early stages (Fig. 1). Osteoplastic changes occurred frequently with occasional osteolytic changes. The tumor speciments in the later development did not show clearly the sites of the osteosarcomas initiated (Fig. 2). Large osteosarcomas with a marked bone formation, such as radiating spicules of periosteal new bone, were common.

Histologically the bone tumors were consistently osteosarcomas composed of osteoblastic, chondroblastic, fibroblastic and other undifferentiated cells of mesenchymal origin (Fig. 3). Osteoid or chondroid deposits were found in all tumor tissues, regularly observed under pseudocapsule of fibroblasts surrounded by osteoblasts, a derivative of the proliferating periosteum. Occurrence of osteoclasts was infrequent. Predominant new bone formation and masses of tumorous osteoids were noted in some areas of tumors. The tumorous stroma consisted of polymorphic cells of large and atypical spindleshape. Histogenesis and histochemical pictures of this tumor are described elsewhere. Histologically and radiologically the present osteosarcomas closely resemble human osteosarcomas.

Summary. Rat-adapted murine sarcoma virus (Moloney) induced csteosarcomas. The process of serial cell-free passages, biological activity of the virus, and radiological and histological features of rat osteosarcomas are described.

Acknowledgments. We are grateful to Emeritus Professor Sajiro Makino, Hokkaido University, for reading through the manuscript. We are indebted to Dr. Kunio Ohta, Tokyo Metropolitan Institute of Gerontology and Professor Iwao Maekawa, Tottori University School of Medicine, for the diagnosis of pathological slides and X-ray films with helpful advice. Our thanks are also due to Mrs. Hiroko Fukami for her technical assistance.

\section{References}

1) Tanaka, K. K., T. O. Yoshida, T. Tanaka, K. Kojima, and T. Hanaichi (1972) : Gann, 63, 445-457.

2) Dmochowski, L., J. L. East, J. M. Bowen, M. L. Lewis, and T. Shigematsu (1972) : Texas Rep. Biol. Med., 30, 301-312.

3) Moloney, J. B. (1960) : J. Nat. Cancer Inst., 24, 933-952. 